\title{
URGENSI PENGESAHAN RANCANGAN UNDANG-UNDANG PERLINDUNGAN DATA PRIBADI DEMI MEWUJUDKAN KEPASTIAN HUKUM
}

\section{Nurmalasari}

Universitas Islam Indonesia (UII) Yogyakarta, Indonesia

Email: nurmalasari211297@gmail.com

\begin{abstract}
Abstrak
Pengumpulan dan penyebarluasan data pribadi merupakan pelanggaran terhadap privasi. Seseorang karena hak privasi mencakup hak menentukan memberikan atau tidak memberikan data pribadi. Namun demikian kurangnya pengaturan mengenai perlindungan data pribadi menyebabkan rentan terjadinya penyalahgunaan didunia maya. Tujuan dari penelitian ini guna melihat urgensi perlunya RUU Perlindungan Data Pribadi disahkan, serta menganalisis tawaran konsep RUU Perlindungan Data Pribadi guna untuk menjadikan landasan bagi penegak hukum. Metode penelitian ini yuridis normatif dengan metode pengumpulan data yaitu studi pustaka dan analisis secara deskriptif analisis. Hasil penelitian menunjukkan bahwa RUU Perlindungan Data Pribadi memang perlu untuk segerah disahkan mengingat banyak hal yang mendorong RUU tersebut, diantaranya mengenai peningkatan kasus pembobolan data pribadi, melindungi dan menjamin hak dasar warga negara, serta agar memberikan kepastian hukum kepada warga negara. Sehingga dengan adanya RUU Perlindungan Data Pribadi ini dapat mengakomodir beberapa asasasas hukum nasional, mulai dari keadilan, kepastian dan kemanfaatan hukum. Selanjutnya mengenai konsep RUU Perlindungan Data Pribadi merupakan upaya pemerintahan untuk membangun landasan atau aturan yang khusus dan komprehensif demi menjaga data pribadi khususnya mengenai hak privasi masyarakat Indonesia, terlebih lagi tuntutan di era kemajuan teknilogi membuat kejahatan semakin komplek dan tak terbatas.
\end{abstract}

Kata Kunci: urgensi pengesahan; RUU perlindungan data pribadi; kepastian hukum

\section{Abstract}

The collection and dissemination of personal data is a violation of privacy. A person's right to privacy includes the right to determine whether or not to provide personal data. However, the lack of regulation regarding the protection of personal data makes it vulnerable to misuse in cyberspace. The purpose of this study is to see the urgency of the need for the Personal Data Protection Bill to be passed, as well as to analyze the draft offer of the Personal Data Protection Bill in order to form the basis for law enforcement. This research method is normative juridical with data collection methods, namely library research and descriptive analysis. The results of the study indicate that the Personal Data Protection Bill does need to be ratified immediately considering that there are many things that encourage the bill, including increasing cases of personal data breaches, protecting and guaranteeing

\begin{tabular}{ll}
\hline How to cite: & Nurmalasari, N. (2021) Urgensi Pengesahan Rancangan Undang-Undang Perlindungan Data Pribadi \\
& Demi Mewujudkan Kepastian Hukum, Syntax Idea, 3(8), https://doi.org/10.36418/syntax- \\
& idea.v6i8.1414 \\
E-ISSN: & 2684-883X \\
Published by: & Ridwan Institute
\end{tabular}


the basic rights of citizens, as well as providing legal certainty to citizens. So with the existence of the Personal Data Protection Bill, it can accommodate several national legal principles, ranging from justice, certainty and legal benefits. Furthermore, regarding the concept of the Personal Data Protection Bill, it is the government's effort to build a special and comprehensive basis or rules in order to protect personal data, especially regarding the privacy rights of the Indonesian people, moreover, demands in the era of technological advances make crime more complex and unlimited.

Keywords: the urgency of endorsement; personal data protection bill; legal certainty

\section{Pendahuluan}

Saat ini teknologi informasi telah berkembang dengan cepat dan pesat, sehingga hal tersebut memberikan sinyal kemudahan yang memungkinkan setiap orang dapat berkomunikasi kesegala penjuru dunia tanpa lagi dibatasi ruang dan waktu. Perkembangan tersebut berupa internet, yang muncul dan memberikan gaya baru bagi masyarakat untuk dijadikan sebagai sarana berkomunikasi. Oleh karena itu dengan kemunculan media elektronik merupakan konsekuensi logis dari revolusi industri 4.0 yang mana cara kerja berpindah dari konvensional menjadi modern (Sinaga 2020).

Ketika hal tersebut terjadi maka tak dapat di pungkiri lagi kemunculan revolusi industri 4.0 yang mengusulkan banyak manfaat, akan tetapi memiliki rintangan yang harus dihadapi oleh suatu negara, yakni dalam bidang hukum, dimana memunculkan persoalan-persoalan seperti internet telah menciptakan dunia bisnis seakan-akan tanpa batas, memberikan banyak manfaat dan kemudahan. Atas dasar kemudahan tersebut tentu mempunya dampak yang begitu besar bagi perlindungan data pribadi. Maka demikian atas permasalahan yang berkaitan dengan penyalahgunaan data dan informasi tersebut mempunyai hubungan dengan hak privasi. Hak privasi sendiri menurut (Kominfo 2015) sebuah perlindungan data juga sebagai elemen kunci bagi kebebasan dan harga diri individu. Perlindungan data menjadi pendorong bagi terwujudnya kebebasan politik, spiritual, keagamaan bahkan kegiatan seksual. Hak untuk menentukan nasib sendiri, kebebasan berekspresi dan privasi adalah hak-hak yang penting untuk menjadikan kita sebagai manusia.

Hak privasi merupakan hak yang melekat pada seseorang untuk tidak atau menentukan, memberikan data pribadinya. Oleh karenanya ketika seseorang dapat mengakses, mengumpulkan ataupun menyebarluaskan data pribadi seseorang maka hal ini menjadi bentuk kejahatan terhadap privasi. Namun demikian di Indonesia sendiri regulasi terhadap perlindungan data pribadi masih dapat dikatakan belum mampu memberikan perlindungan yang secara utuh terhadap data pribadi, khususnya korban. Hal ini dapat dibuktikan pada regulasi-regulasi yang masih bersifat sektoral dan masih bertebaran dan juga masih mencerminkan secara umum, yakni sebagaimana dalam peraturan perundang-undangan yakni Undang-Undang Nomor 7 Tahun 1971 tentang Ketentuan-Ketentuan Pokok Kearsipan, Undang-Undang Nomor 10 Tahun 1998 tentang Perubahan atas Undang-Undang Nomor 7 Tahun 1992 tentang Perbankan, Undang- 

Mewujudkan Kepastian Hukum

Undang Nomor 36 Tahun 1998 tentang Dokumen Perusahaan, Undang-Undang Nomor 36 Tahun 1999 tentang Telekomunikasi, Undang-Undang Nomor 23 Tahun 2006 tentang Administrasi Kependudukan, Undang-Undang Nomor 36 Tahun 2009 tentang Kesehatan, serta Undang-Undang Nomor 11 Tahun 2008 tentang Informasi dan Transaksi Elektronik yang kemudian diamanatkan lagi dalam peraturan Pemerintah Nomor 82 Tahun 2012 tentang Penyalahgunaan Sistem dan Transaksi Elektronik.

Dengan demikian secara filosofis, yuridis dan sosiologis dijelaskan diatas, masih minimnya dalam penyediaan pengaturan tentang perlindungan data pribadi, serta masih bersifat persial dan sektoral menyebabkan beberapa kasus yang tak terduga di dalam dunia siber belum bisa memberikan perlindungan yang optimal dan efektif terhadap data pribadi.

Berkaitan dengan penelusuran di lapangan dalam rentan waktu tiga tahun terakhir diketahui terdapat kebocoran data pribadi dari BPJS Kesehatan mencapai angka 279 juta, Bukalapak pada tahun 2020, dan juga Tokopedia. Hal inilah kemudian menjadikan sangat penting untuk menyusun dan segerah mengesahkan Undang-Undang Perlindungan Data Pribadi, guna menjamin keamaan data pribadi masyarakat. Dengan demikian perlindungan data pribadi memang menjadi isu yang harus diperhatikan. Mengapa demikian, karena data pribadi menjadi hal yang sensitif karena aktivitas pengelolaan data yang akan memudahkan identifikasi kelompok atau individu yang justru berpotensi membahayakan pribadi orang tersebut.

Atas dasar uraian penelusuran tersebut, banyak ditemukan kasus dan permasalahan yang berkaitan dengan penyalahgunaan data dan informasi (Sautunnida, Jurnal, and Hukum 2012). Sehingga mempunyai implikasi pada eksistensi hukum yang mengaturnya. Oleh karena itu perlu diberikan sentuhan hukum, agar eksistensi negara hukum dapat terus dipertahankan.

Selain dari pada itu, pengaturan mengenai perlindungan data pribadi akan meminimalisirkan ancaman penyalahgunaan data pribadi di sektor industri perbankan, situs pertemanan online seperti (Facebook, My Space, Twitter, Path, Google Plus), program KTP elektronik, e-health. Potensi terjadinya kejahatan yang berawal dari pencarian data pribadi seseorang, penghilangan identitas atas data dari pelaku kejahtan, search mesin pencarian, misanya google.com dan bing.com, dan juga cloud computing. Oleh karena itulah atas dasar pertimbangan semua ancaman dan potensi pelanggaran diatas, maka pengaturan perlindungan data pribadi dimakudkan untuk melindungi kepentingan konsumen dan memberikan manfaat bagi Indonesia (Kominfo 2015).

Dengan demikian dapat disimpulkan bahwa Indonesia belum memiliki aturan perundang-undangan secara khusus mengatur mengenai perlindungan data pribadi, sehingga untuk melindungi masyarakat dan mengatur masalah perlindungan atas data pribadi dan menyiapkan berbagai bentuk perlindungan hukum merupakan sebuah konsekuensi logis dari Indonesia negara hukum, artinya tindakan apapun harus dilandasi oleh hukum, serta melihat pada Undang-Undang Nomor 17 Tahun 2007 tentang Rencana Pembangunan Jangka Panjang 2005-2025 juga telah ditentukan bahwa untuk mewujudkan bangsa yang berdaya saing harus meningkatkan pemanfaatan ilmu 
pengetahuan dan teknologi, salah satunya yakni melalui peraturan yang terkait dengan privasi (Kominfo 2015).

Oleh karena itulah penulis tertarik untuk dikaji serta dianalisis terhadap urgensi pengesahan RUU Perlindungan Data tesebut. Terlepas dari pada itu perlu diketahui bahwa penelitian penulis ini mempunyai nilai kebaruan yang terletak pada konsep RUU Perlindungan Data Pribadi yang diantaranya mengenai konsep, jangkauan, arah pengaturan dan juga ruang lingkupnya, mengapa demikian menjadi nilai kebaruannya. Agar ketika RUU Perlindungan Data Pribadi ketika diterapkan dan di sahkan tidak lagi menjadi kebijakan hukum pidana yang saling kontradiktif atau ketidakjelasan rumusan. Oleh sebab itu perlu kiranya untuk menganalisis atau mengkaji RUU Perlindungan Data tersebut.

\section{Metode Penelitian}

Dalam hal penelitian ini menggunakan metode penelitian yuridis normatif. Adapun langkah langkah yang dilakukan adalah melalui studi kepustakaan yang menelaah data sekunder berupa bahan hukum primer dan bahan hukum sekunder. Bahan hukum primer meliputi Undang-Undang Dasar Negara Republik Indonesia Tahun 1945, Undang-Undang Nomor 39 Tahun 1999 tentang Hak Asasi Manusia, Undang-Undang Nomor 36 Tahun 1999 tentang Telekomunikasi, Undang-Undang 23 Tahun 2006 tentang Administrasi Kependudukan telah diubah dengan Undang-Undang Nomor 24 Tahun 2013 tentang Perubahan Undang-Undang Nomor 23 Tahun 2006 tentang Administrasi Kependudukan, Undang-Undang Nomor 14 Tahun 2008 tentang Keterbukaan Informasi Publik, Undang-Undang Nomor 11 Tahun 2008 tentang Informasi dan Transaksi Elektronik dan perjanjian internasional yang telah disahkan serta berbagai peraturan perundang-undangan terkait lainnya. Sedangkan bahan hukum sekunder diperoleh melalui pengkajian hasil-hasil penelitian, buku-buku, jurnal ilmiah, dan yurisprudensi, serta bahan pustaka lainnya yang membahas mengenai perlindungan atas data pribadi. Adapun untuk menganalisis data sekunder digunakan metode kualitatif sedangkan metode penelitiannya menggunakan deskriptif analitis.

\section{Hasil dan Pembahasan}

\section{Urgensi Perlunya RUU Perlindungan Data Pribadi Disahkan}

\section{a. Meningkatnya Kasus Pembobolan Data Pribadi}

Dalam masa pandemi covid-19 ini tentu membuat banyak kegiatan beralih ke ruang digital, sehingga mengubah gaya hidup mulai dari belajar, bekerja hingga berbelanja. Maka tak heran jika masyarakat memiliki ketergantungan pada teknologi digital. Namun demikian hal tersebut tentu mempunyai potensi ancaman serangan siber. Dapat dilihat sejumlah platform belanja online paling banyak menghadapi serangan siber sepanjang tahun 2020. Bahkan juga lembaga negara menjadi potensi ancaman para pelaku kejahatan siber dengan modus operandi mengincar data pribadi para pengguna platfrom dengan meretas. Berikut rangkuman kasus kebocoran data yang terjadi sepanjang tahun 2020: 
1) Tokopedia

Di awal bulan Mei 2020 terdapat 91 juta data pengguna dan lebih dari 7 juta data merchant Tokopedia dikabarkan dijual gelap. Penjualan data Tokopedia mencakup gender, lokasi, username, nama lengkap, alamat email, nomor ponsel, dan password.

2) Bhineka.com

Kelompok peretas yang bernama ShinyHunters mengklaim bahwa telah membobol sepuluh perusahaan, salah satunya e-commerce $\mathrm{b}$ to $\mathrm{b}$ asal Indonesia, kelompok peretas tersebut yang kabarnya juga dalang Tokopedia, dilaporkan membobol 1,2 juta data pengguna. Kelompok peretas tersebut menjual di pasar web gelap atau dark web.

3) KPU

Peretas telah membobol 2,3 juta data warga Indonesia dari Komisi Pemilihan Umum, serta pertas tersebut telah membocorkan informasi.

4) Data Pasien Cocovid-19

Keamanan data diri pasien Covid-19 dipertaruhkan. Pasalnya data yang selama ini selalu dirahasiakan oleh pemerintahan, kini telah diperjualbelikan oleh peretas atau hacker. Mucul kabar yang menyebutkan peretasan basis data Covid-19. Pelaku peretasan atas nama database Shopping di dark web rainforums telah menjual data pasien Covid-19 di Indonesia, fitur spoiler di situs gelap menunjukkan data yang diambil antara berupa ID pengguna, jenis kelamin, usia, nomor telepon, alamat tinggal hingga status pasien.

\section{b. Melindungi dan Menjamin Hak Dasar Warga Negara Terkait Dengan Perlindungan Data Pribadi}

Sebelum mengerucut pada titik pembahasan terlebih dahulu kita akan mengenal apa sebenarnya data pribadi itu. Pengertian data pribadi merupakan identitas seseorang untuk dapat dikenali, seperti nama, umur, jenis kelamin, pendidikan, pekerjaan, dll. Sehingga data pribadi tidak dapat dipisahkan oleh konsep privasi. Konsep privasi sendiri menurut Charles Fried mendefinisikan sebagai "Kontrol atas pengetahuan diri sendiri" yang diperlukan untuk melindungi hubungan mendasar dari rasa homat, cinta, persahabatan dan kepercayaan (Wahyudi Djafar 2019) Dengan demikian dapat disimpulkan bahwa data pribadi yang merupakan hak privasi seseorang yang tidak dapat diganggu dan dirampas oleh siapapun termasuk negara. Oleh karenannya seseorang dapat membatasi ruang lingkup informasi pribadi hanya untuk berhubungan dengan individu. Sehingga mengumpul dan penyebarluasan data pribadi merupakan pelanggaran terhadap privasi seseorang, karena hak privasi mencakup hak menentukan memberikan atau tidak memberikan data pribadi.

Perlindungan terhadap data pribadi merupakan hak asasi manusia sebagai bagian dari privasi yang telah mendapatkan legitimasi jaminan perlindungan baik instrumen hukum internasional dan juga konstitusi yang diatur dalam 
amandemen keempat UUD 1945, dan di implementasikan dalam UndangUndang Nomor 39 Tahun 1999 tentang Hak Asasi Manusia yang diantaranya menjamin perlindungan hak atas privasi warga negara (Sinaga 2020), sebagai berikut:

1) Pasal 14 ayat 2 menyatakan bahwa, setiap orang berhak untuk mencari, memperoleh, memiliki, menyimpan, mengelolah, dan menyampaikan informasi dengan menggunakan segala jenis sarana yang tersedia.

2) Pasal 29 ayat 1 menyatakan bahwa, setiap orang berhak atas perlindungan diri pribadi, keluarga, kehormatan, martabat, dan hak miliknya.

3) Pasal 31 menyatakan bahwa, (1) tempat kejadian siapapun tidak boleh diganggu, (2) menginjak atau memasuki suatu pekarangan tempat kediaman atau memasuki suatu rumah bertentangan dengan kehendak orang yang mendiaminya, hanya diperbolehkan dalam hal-hal ditetapkan oleh UndangUndang.

Menurut (Wahyudi Djafar 2019) Sedangkan dalam hukum internasional dalam hal ini hak atas privasi diatur secara khusus dalam Pasal 12 Deklarasi Universal Hak Asasi Manusia (DUHAM) yang menegaskan bahwa:

"Tidak seorangpun boleh diganggu secara sewenang-wenang dalam urusan pribadi, keluarga, rumah tangga atau hubungan surat menyurat, juga tidak boleh dilakukan serangan terhadap kehormatan dan reputasinya. Setiap orang berhak mendapatkan perlindungan hukum terhadap gangguan atau penyerangan seperti itu."

Kemudian juga diatur dalam Pasal 17 Kovenan Internasional Hak Sipil dan Politik (ICCPR) yang menjadi instrumen hukum mengikat bagi negara peserta perjanjian, yang mana menegaskan bahwa: (Wahyudi Djafar 2019)

1) Tidak boleh seorang pun yang dapat secara sewenang-wenang atau secara tidak sah dicampuri masalah-masalah pribadinya, keluarganya, rumah atau hubungan surat menyurat, atau secara tidak sah diserang kehormatan dan nama baiknya.

2) Setiap orang berhak atas perlindungan hukum terhadap campur tangan atau serangan seperti tersebut diatas.

Senada dengan pandangan John Locke menyatakan bahwa hak asasi manusia adalah hak-hak yang diberikan langsung oleh Tuhan Yang Maha Pencipta sebagai hak yang kodrati. Oleh karena itu, tidak ada kekuasaan apapun di dunia yang dapat mencabutnya. Hak ini merupakan sifat yang paling mendasar (fundamental) bagi hidup dan kehidupan manusia dan merupakan hak kodrati yang tidak bisa terlepas dari dalam kehidupan manusia (Upik Mutiara 2020).

Pada dasarnya pijakan negara Indonesia sebagai negara hukum yakni dapat dilihat pada Pasal 1 ayat 3 UUD 1945 Perubahan ketiga yang berbunyi "Negara Indonesia adalah negara hukum. Diadobsinya ketentuan ini kedalam bagian 
Pasal UUD 1945 menunjukkan semakin kuatnya dasar hukum serta menjadi amanat negara, bahwa Indonesia adalah negara hukum (Winarno 2007).

Menurut pandangan Wirjono Prodjojodikoro, negara hukum adalah negara yang berdiri di atas hukum yang menjadi keadilan kepada warga negaranya. Keadilan yang merupakan syarat bagi tercapainya kebahagiaan hidup untuk warga negaranya. Demikian juga pada halnya peraturan hukum yang harus mencerminkan rasa keadilan bagi pergaulan hidup antar warga negaranya (Jumiati 2006).

Sedangkan hukum memiliki ciri-ciri yang berbeda dengan kaidah-kaidah sosial lainnya maupun dengan kaidah agama, yang ciri hukum tersebut menurut Pandangan Soerjono Soekanto dikutip oleh (Gunakaya 2017) sebagai berikut:

1) Hukum bertujuan untuk menciptakan keseimbangan di antara kepentingankepentingan yang terdapat dalam masyarakat.

2) Mengatur perbuatan manusia secara lahiriah.

3) Dijalankan oleh badan-badan yang diakui oleh masyarakat sebagai badan pelaksana hukum. Dalam masyarakat sederhana badan serupa ini dapat berupa kepala adat, dewan para sesepuh atau lainnya.

Dengan demikian dapat dipahami bahwa hukum suatu kumpulan peraturan atau kaidah yang mempunyai isi yang bersifat umum dan normatif. Bersifat umum karena berlaku bagi setiap orang, sedangkan bersifat normatif karena menentukan apa yang seyogyanya atau seharusnya dilakukan (Gunakaya 2017). Artinya, hukum itu mengayomi atau melindungi manusia dalam masyarakat, berbangsa dan bernegara. Dalam sebuah teori yang membahas tentang hukum kita kenal dengan a tool of social enginering, yakni hukum sebagai alat mengubah masyarakat. Oleh karena itu hukum sebagai insturmen kontrol sosial di dalam masyarakat, serta menetapkan tingkah laku mana yang dianggap sebagai penyimpangan terhadap aturan hukum dan bagaiamana ketika aturan tersebut di langgar apa sanksi atau tindakan yang dilakukan manakala terjadi penyimpangan (Gunakaya 2017).

Dengan demikian yang dijelaskan diatas bahwa secara filosofis perlindungan data pribadi menjadi manifestasi terhadap pengakuan dan perlindungan atas hak-hak dasar manusia sesuai dengan nilai-nilai Pancasila (Gunakaya 2017). Lalu bagaimanakah pengaturan terkait hak privasi di Indonesia?. Hingga saat ini pengaturan terkait hak privasi masih dalam bentuk bersifat persial dan sektoral menyebabkan beberapa kasus yang tak terduga di dalam dunia siber belum bisa memberikan perlindungan yang optimal dan efektif terhadap data pribadi. Dapat dilihat beberapa Undang-Undang yang dimaksud yakni: (1)Undang-Undang Nomor 7 Tahun 1992 tentang Perbankan sebagaimana diubah dengan Undang-Undang Nomor 10 Tahun 1998 tentang Perbankan, (2) Undang-Undang Nomor 36 Tahun 1999 tentang Telekomunikasi, (3) Undang-Undang Nomor 8 Tahun 1999 tentang Perlindungan Konsumen, (4) Undang-Undang Nomor 39 Tahun 1999 tentang Hak Asasi Manusia, (5) 
Undang-Undang Nomor 23 Tahun 2006 tentang Administrasi Kependudukan, (6) Undang-Undang Nomor 11 Tahun 2008 tentang Informasi dan Transaksi Elektronik, (7) Undang-Undang Nomor 14 Tahun 2008 tentang Keterbukaan Informasi Publik, (9) Undang-Undang Nomor 36 Tahun 2009 tentang Kesehatan, (10) Undang-Undang Nomor 21 Tahun 2011 tentang Otoritas Jasa Keuangan, dan masih banyak yang bertebaran di luar lainnya.

Dari beberapa Undang-Undang dijelaskan diatas dapat dipahami bahwa perlindungan data pribadi yang merupakan sebuah konsep hak privasi masih dalam tataran sektoral, artinya Undang-Undang yang disebutkan diatas masih belum memuat aturan perlindungan data pribadi secara tegas dan komprehensif, serta dalam Undang-Undang itupun hanya mengatur ketentuan umum dan tidak menjelaskan berbagai isu masalah yang banyak dibicarakan di level Internasional (Syarpani 2014).

Hingga saat ini Indonesia yang telah memiliki beberapa regulasi sektoral berkaitan dengan perlindungan data pribadi. Regulasi sektoral pada dasarnya memiliki karakteristik tersendiri, oleh karena itu tentu dalam cakupan nasional diperlukan suatu peraturan yang komprehensif. Di satu sisi hal tersebut sangat relevan juga dalam membangun sistem perlindungan data pribadi (Komin 2021).

Oleh karena itulah salah satu dari perlunya RUU Perlindungan Data Pribadi disahkan yakni secara filosofisnya negara Indonesia negara hukum, maka sudah barang tentu penegak hukum dalam hal ini sebagai alat negara untuk mempertahankan kemerdekaan, tata tertib, hukum dan sebagainya. Berkaitan dengan hal tersebut, Sudikno Mertokusumo berpendapat bahwa hukum berfungsi sebagai alat untuk memberikan perlindungan kepentingan manusia, sedangkan menurut Philpus M. Hadjon berpendapat bahwa tujuan utama dari negara hukum adalah memberikan perlindungan hukum bagi rakyatnya. Perlindungan hukum bagi rakyat atas tindakan pemerintah dilandasi oleh dua prinsip yaitu prinsip hak asasi manusia dan prinsip negara hukum (Setiadi 2017).

Lebih lanjut mengenai pemerintah, dalam hal ini peran dan fungsi pemerintahan yang dikemukakan oleh P.Siagian berpendapat bahwa ada 3 bentuk negara yaitu political state (semua kekuasaan dipegang oleh raja sebagai pemerintah), bentuk legal state (pemerintah hanya sebagai pelaksana peraturan) dan bentuk welfare state (tugas pemerintah diperluas untuk menjamin kesejahteraan umum), dengan directionary power dan freies emessen (Marbun 2006). Oleh karena itu kekuasaan diartikan secara yuridis, maka kekuasaan disebut sebagai suatu pembatasan Undang-Undang (Bakhri 2018).

Selanjutnya menurut Solly Lubis, ada beberapa hal yang harus diperhatikan dalam membentuk sebuah peraturan perundang-undangan harus terpenuhi syarat peraturan perundangan-undangan yang ideal antara lain:

1) Peraturan itu memberikan keadilan bagi yang berkepentingan, dalam hal ini warga negara tanpa terkecuali. 
2) Peraturan hukum itu memberikan kepastian hukum, artinya bahwa dengan berlakunya peraturan itu akan jelas batas-batas hak (recht, right) dan kewajiban (plicht, duty) semua pihak yang terkait dalam suatu hubungan hukum.

3) Peraturan itu memberikan manfaat yang jelas bagi yang berkepentingan dengan kehadiran peraturan itu. Umumnya, jika dua syarat terdahulu sudah dipenuhi maka syarat yang ketiga ini akan dipenuhi juga (Lubis 2009).

\section{c. Memberikan Kepastian Hukum Kepada Masyarakat}

Hukum dan masyarakat mempunyai korelasi yang sangat erat, artinya, bahwa hukum dan masyarakat tidak dapat dipisahkan, mengacu pada ungkapan ubi societas ibi ius. Dari ungkapan tersebut mengisyaratkan bahwa kehidupan bersama tentu tidak cukup diberikan pada i'tikad baik maupun kesadaran moral pribadi, melainkan perlu melahirkan suatu norma untuk mengatur hidup bersama agar mewujudkan ketertiban dan keadilan. Hal ini memang perlu untuk diwujudkan, karena didalam suatu masyarakat tentu juga tak terlepas dari sebuah konflik yang kemudian sulit untuk dihindarkan, maka dengan demikian adanya norma hukum konflik tersebut dapat diharapkan sebagai katub penyelamat dan dapat memecahkan secara berkeadilan dengan parameter yang lebih objektif (Suliantoro 2017).

Masyarakat Indonesia pada saat sekarang ini telah mengalami proses perubahan akibat dari pengaruh eksternal dalam bentuk globalisasi serta gejolak dinamika internal berupa pencarian jati diri. Masa transisi bersifat simultan akbiat dari adanya proses transformasi sosial budaya yang berlangsung secara cepat memunculkan persoalan yang bersifat kompleks (Suliantoro 2017). Masa transisi tersebut kemudian diikuti berbagai perubahan fundamental, baik menyangkut perilaku/sikap, pola pikir bahkan cara pandang masyarakat terhadap dunianya, akibatnya menimbulkan problematika yang kompleks, seperti dalam bidang hukum, khususnya menyangkut aspek kepastian hukum (Suliantoro 2017) kepastian hukum dalam suatu peraturan hukum terdapat asas-asas hukum yang menjadi dasar atau titik anjak pembentukannya. Menurut Satjipto Rahardjo mengatakan bahwa asas hukum dapadiartikan sebagai "jantungnya" peraturan hukum (Rahardjo 2012). Oleh karena itu untuk memahami suatu peraturan hukum diperlukan adanya asas hukum. Dengan kata lain, Karl Larenz menyampaikan bahwa asas hukum merupakan parameter hukum ethis yang memberikan arah kepada pembentuk hukum. Sehingga asas hukum mengandung tuntutan etis yang dapat dikatan sebagai jembatan antara peraturan hukum dengan cita-cita sosial dan pandangan etis masyarakat (Mario Julyano 2019).

Menurut Gustaf Radbruch dalam konsep ajaran "Prioritas Baku", mengemukakan ada tiga ide dasar hukum atau tiga tujuan hukum adalah keadilan, kemanfaatan dan kepastian hukum. Keadilan yang merupakan hal paling utama dari ketiga hal itu, namun demikian tidak berarti dua unsur yang lain dapat dengan serta merta diabaikan. Mengingat akan hal bahwa hukum yang 
baik adalah hukum yang mampu mensinergikan ketiga unsur tersebut demi kesejateraan dan kemakmuran masyarakat (Prayogo 2016).

Sedangkan menurut Utrech, "Kepastian hukum merupakan aturan yang bersifat umum sehingga individu mengetahaui perbuat apa yang boleh atau tidak boleh dilakukan, dan juga merupakan keamanan hukum bagi individu dari kesewenangan pemerintah" (Syahrani 1999). Dengan demikian dapat dipahami bahwa kepastian hukum merupakan sebuah jaminan atas perlindungan yang yustisiable terhadap tindakan sewenang-wenang. Oleh karena itulah kepastian hukum memerlukan tersedianya perangkat peraturan perundang-undangan yang secara operasional maupun mendukung pelaksanaannya (Prayogo 2016).

Bertitik tolak pada asas-asas hukum tersebut Gustaf Radbruch lebih jauh memberikan pemaknaan tentang kepastian hukum yakni kondisi dimana hukum dapat berfungsi sebagai peraturan yang harus ditaati (Huijbers 1982). Oleh karenanya, menurut Fance M. Wantu, "Hukum tanpa nilai kepastian hukum akan kehilangan makna karena tidak lagi dapat dijadikan pedoman perilaku bagi semua orang" (M.Wantu 2007). Dengan demikian dapat dipahami bahwa kepastian hukum merupakan aturan hukum yang jelas dan tegas dan kemudian mendapatkan legalitas agar dapat digunakan sebagaimana mestisnya.

Ketiadaan hukum mengenai perlindungan data pribadi yang masih bersifat umum di Indonesia dapat dikatakan sebagai suatu kelemahan yang menyebabkan beberapa perusahaan tidak memilih Indonesia sebagai lokasi untuk pusat penyimpanan datanya. Padahal perkembangan pengaturan perlindungan data pribadi akan mendukung pembangunan masa depan Indonesia sebagai pusta data global (Kominfo 2015). Oleh karenanya pengaturan tentang data pribadi sangat diperlukan, mengingat mengatur mengenai pengumpulan, penggunaan, pengungkapan, pengiriman dan keamanan data pribadi dan secara umum pengaturan adalah untuk mencari keseimbangan antara kebutuhan akan perlindungan data pribadi individu dengan kebutuhan pemerintah dan pelaku bisnis untuk memperoleh dan memproses data pribadi untuk keperluan yang wajar dan sah (Kominfo 2015).

Dalam konteks ini yang dijelaskan diatas tentu mempunyai korelasai terhadap perlindungan data pribadi, dimana ketika peraturan perundangundangan yang menyangkut perlindungan data pribadi masih bersifat sektoral dan masih bertebaran di luar, artinya bahwa peraturan perundangan-undangan yang menyangkut hal tersebut masih dalam pembahasan umum yang substansinya belum dapat dikatakan sepenuhnya mengatur secara khusus tentang perlindungan data pribadi dalam hal ini hak privasi. Kendatipun demikian tentu sangat mempengaruhi penegakan hukum dalam sistem peradilan pidana di Indonesia.

Oleh karena itu kepastian hukum sangat menentukan dalam penyelesaian perkara hukum, agar dalam proses hukum tidak terjadi kesewenangan dan tetap dalam koridor peraturan yang ada di Indonesia. Tanpa adanya kepastian hukum 
masyarakat tidak pernah mengerti apakah perbuatan yang akan masyarakat perbuat benar ataukah salah dan tanpa adanya suatu kepastian hukum akan menimbulkan berbagai permasalahan yaitu timbulnya suatu keadaan yang meresahkan masyarakat. Oleh karena itu kepastian hukum sangat dibuthkan dalam masyarakat untuk memperoleh perlindungan dari tindakan yang sewenang-wenang dari berbagai aparat penegak hukum dalam menjalankan tugasnya ada dalam masyarakat (Kania Dewi Andhika Putri 2018).

Bertitik tolak pada memberikan kepastian hukum, perlu diketahui bahwa data dan informasi memiliki peran yang sangat signifikan terhadap kehidupan masyarakat di abad ke-21 terutama dala bidang penyelenggara pemerintahan, kegiatan bisnis maupun perdagangan berkenaan dengan data pribadi, mulai dari tingkat nasional, regional hingga internasional. Kemunculan RUU Perlindungan Data Pribadi ini akan mengantarkan pada suatu sistem administrasi pemerintahan yang efisien dan efektif dalam memberikan pelayanan bagi masyarakat. Kondisi peraturan perundang-undangan tersebut telah menjadikan adanya kebutuhan suatu Undang-Undang yang mampu menjamin perlindungan bagi seseorang atas data an informasinya. Kebutuhan akan regulasi terhadap berbagai aktivitas yang melibatkan pemanfaatan teknologi informasi dan komunikasi dirasakan samikin urgent. Mengingat akan hal aktivitas-aktivitas tersebut telah mempengaruhi dan bahkan merubah paradigma di barbagai bidang, khususnya pada bidang informasi dan teknologi.

Dengan demikian penjelasan diatas tersebut menunjukkan betapa pentingnya RUU Perlindungan Data Pribadi disahkan, sehingga dengan adanya regulasi tersebut dapat mengakomodir hak asasi manusia, khususnya hak privasi dan juga regulasi RUU Perlindungan Data Pribadi.

d. Konsep RUU Perlindungan Data Pribadi Mengenai Jangkauan, Arah Pengaturan, Dan Ruang Lingkup

Kehadiran RUU Perlindungan Data Pribadi merupakan upaya pemerintahan untuk membangun landasan atau aturan yang khusus dan komprehensif demi menjaga data pribadi khususnya mengenai hak privasi masyarakat Indonesia, terlebih lagi tuntutan di era kemajuan teknilogi membuat kejahatan semakin komplek dan tak terbatas. RUU Perlindungan Data Pribadi ini disamping mengenai aturan yang khusus dan komprehensif juga dapat mengharmonisasikan kehadiran undang-undang dari masing-masing sektor kerja seperti yang terdapat pada undang-undang ITE dan turunannya. Mengapa demikian, karena undang-undang yang membahas tentang perlindungan data pribadi disebutkan diatas belum dapat menghadirkan asas/prinsip yang terkait perumusan norma. Hal demikian perlu diperhatikan karena merupakan prasyarat terjadinya keadilan, ketidakberpihakan dan dimensi moralitas lainnya. Di samping itu menurut pandangan (Rahardjo 2000) "Asas hukum dapat dikatakan sebagai alasan bagi pembentukan/lahirnya sebuah peraturan hukum, atau biasa disebut dengan ratio legis dari peraturan hukum”. 
Dalam membentuk suatu peraturan perundang-undangan tentu harus berdasarkan asas pembentukan peraturan perundang-undangan agar semaksimal mungkin dapat mencapai kesejahteraan spritual dan materiil bagi masyarakat maupun individu dan juga sebagai sarana untuk memperoleh keadilan. Dengan demikian ada beberapa asas yang harus diperhatikan ketika ingin membentuk sebuah peraturan perundang-undangan yakni:

1) Asas Kejelasan Tujuan

2) Asas Kelembagaan atau Pejabat Pembentuk Yang Tepat

3) Asas Kesesuaian Antara Jenis, Hirerarki dan Materi Muatan

4) Asas Dapat Dilaksanakan

5) Asas Kedayagunaan dan Kehasilgunaan

6) Asas Kejelasan Rumusan

7) Asas Keterbukaan.

Dengan demikian yang telah disebutkan diatas mempunyai hubungan dengan RUU Perlindungan Data Pribadi. Mengapa demikian dikatakan, RUU Perlindungan Data Pribadi sebuah jawaban tentang persoalan dari ketidaksinkronaan Undang-Undang sebelumnya yang masih bersifat sektoral dan juga masih tumpang tindihnya tentang perlindungan data pribadi. Dari persoalan diatas dapat dikatakan bahwa regulas-regulasi yang mengatur tentang perlindungan data pribadi tersebut tidak memberikan sebuah kepastian hukum. Sedangkan berkaca pada Undang-Undang No 10 Tahun 2004 yang pada intinya menyatakan bahwa dari segi kepastian hukum dalam pembentukan peraturan perundang-undangan yang mana dalam setiap ketentuan yang telah diatur dalam Undang-Undang No 10 Tahun 2004, menyatakan bahwa dengan terbitnya Undang-Undang tersebut terasa bahwa pembentukan peraturan semakin seragam baik dari sisi substansi maupun sistematika penuangannya. Oleh karena itu kehadiran RUU Perlindungan Data Pribadi merupakan penyempurnaan regulasi pada Undang-Undang yang sudah ada sebelumnya. Maka tak heran jika masyarakat mendorong agar RUU Perlindungan Data Pribadi segera disahkan.

Berbicara mengenai regulasi tentu akan berbicara mengenai UndangUndang, maka dalam pokok pembahasan pada rumusan kedua ini mengenai konsep perlindungan data pribadi, mengenai jangkauan, arah pengaturan dan juga ruang lingkup.

1) Konsep Perlindungan Data Pribadi Di Dalam RUU Perlindungan Data Pribadi Serta Asas-Asas Bidang Hukum Perlindungan Data Pribadi

Konsep perlindungan data pribadi mengisyaratkan bahwa individu memiliki hak untuk menentukan apakah ia akan bergabung dengan masyarakat kemudian akan membagi atau bertukar data pribadi diantara mereka serta hak untuk menentukan syarat-syarat apakah yang harus dipenuhi untuk melakukan hal tersebut. Hukum perlindungan data pribadi secara umum juga mencakup langkah-langkah pengamanan perlindungan dari 
keamanan data pribadi dan memperbolehkan penggunaannya oleh orang lain sepanjang sesuai dengan ketentuan atau syarat (Dewi 2016).

Dengan adanya konsep perlindungan data pribadi ini tentu dapat melindungi data pribadi individu terhadap penyalahgunaan pengumpulan, khususnya bagi konsumen yang sangat membutuhkan perlindungan hukum terutama di era dimana data pribadi menjadi lebih sangat berharga bagi kepentingan bisnis, menimbulkan kekhawatiran bahwa data pribadi konsumen dijual atau digunakan tanpa adanya persetujuan mereka.

Namun demikian, di Indonesia pengaturan privasi dan perlindungan data pribadi. tidak dapat ditemukan dalam satu peraturan, akan tetapi para sarjana selalu merujuk pada Pasal 28 G Undang-Undang Dasar Negara Republik Indonesia 1945 sebagai titik anjak untuk membuat peraturan khusus tentang perlindungan data pribadi, sebagaimana bunyi Pasal 28 G UUD 1945 menyatakan.

"Setiap orang berhak atas perlindungan atas perlindungan diri pribadi, keluarga, kehormatan, martabat, dan harta benda yang di bawah kekuasaannya, serta berhak atas rasa aman dan perlindungan dari ancaman ketakutan untuk berbuat atau tidak berbuat sesuatu yang merupakan hak asasi manusia”.

Berdasarkan tersebut tidak secara eksplisit menyebutkan mengenai privasi dan perlindungan data pribadi, melainkan ketentuan tersebut hanya menjelaskan tentang perlindungan hak asasi manusia.

Bertitik tolak pada penjelesan diatas, maka sudah searah dan sejalan apa yang menjadi konsep perlindungan data pribadi di dalam Naskah Akademik RUU Perlindungan Data Pribadi (Kominfo 2015) menjelaskan bahwa:

"Pengaturan yang akan disusun diharapkan dapat melindungi data pribadi individu terhadap penyalahgunaan pengumpulan serta pengolahannya dipermudah dengan teknologi informasi dan komunikasi saat ini. Perkembangan pengaturan data pribadi secara umum akan menempatkan Indonesia sejajar dengan negara-negara dengan tingkat perekonomian yang maju, yang telah menerapkan hukum mengenai perlindungan data pribadi. Dengan demikian akan lebih mendorong dan memperkuat posisi Indonesia sebagai pusat bisnis terpercaya, yang merupakan suatu strategi kunci dalam ekonomi nasional Indonesia. Pengaturan tentang data pribadi sangat diperlukan karena mengatur mengenai pengumpulan, penggunaan, pengungkapan, pengiriman dan keamanaan data pribadi dan secara umum pengaturan data pribadi adalah untuk mencari keseimbangan antara kebutuhan akan perlindungan data pribadi individu dengan kebutuhan Pemerintahan dan Pelaku Bisnis untuk memperoleh dan memproses data pribadi untuk keperluan yang sewajarnya”. 
Sedangkan mengenai asas-asas dalam pembentukan RUU Perlindungan Data Pribadi perlu diperhatikan, mengingat asas-asas tersebut sebagai dasar dari perumusan norma dalam RUU Perlindungan Data Pribadi yakni:

a. Asas Perlindungan

Dalam RUU Perlindungan Data Pribadi telah memuat asas perlindungan. Mengapa demikian, asas perlindungan Menurut Philipus M. Hadjon dalam (sinta.unud.ac.id n.d.) "Perlindungan hukum merupakan harkat dan martabat dan pengakuan terhadap hak asasi manusia yang dimiliki oleh subyek hukum dalam negara hukum dengan berdasarkan ketentuan hukum yang berlaku di negara tersebut guna mencegah terjadinya kesewenang-wenangan. Perlindungan hukum itu pada umumnya berbentuk suatu peraturan tertulis, sehingga sifatnya lebih mengikat dan akan mengakibatkan adanya sanksi yang harus dijatuhkan kepada pihak yang melanggarnya". Maka demikian RUU Perlindungan Data Pribadi menjadi kelak dimaksudkan untuk memberi perlindungan kepada pemilik data mengenai privasinya, mengenai data pribadi, mengenai hak-hak atas dasar agar data tersebut tidak disalhgunakan.

b. Asas Kepentingan Umum

Kepentingan umum menurut Jazim Hamidi (Pratiwi et al. 2016) memberikan indikator atau unsur-unsur yang termuat di dalam asas kepentingan umum yaitu: untuk kepentingan nasional, bangsa, dan negara, kepentingan pembangunan, kepentingan masyarakat, dan ada dasar peraturan perundang-undangannya.

Merujuk pada pandangan tersebut, maka dalam RUU Perlindungan Data Pribadi menjelaskan bahwa asas kepentingan umum sangat penting untuk menjadi salah satu asas dari RUU tentang Perlindungan Data Pribadi, karena kepentingan umumlah yang dapat dijadikan alasan yang sah, sesuai dengan rumusan Undang-Undang, sebagai alasan untuk menerobos atau alasan pengecualian terhadap perlindungan privasi atas data pribadi. Kepentingan umum tersebut meliputi, keamanan negara, kedaulatn negara, pemberantasan korupsi dan tindak pidana lainnya (Kominfo 2015).

c. Asas Pertanggungjawaban

Asas pertanggungjawaban memberi landasan bagi semua pihak yang terkait dengan pemrosesan, penyebarluasan, pengelolahan, dan pengawasan data pribadi untuk bertindak secara bertanggung jawab sehingga mampu menjamin keseimbangan hak dan kewajiban para pihak yang terkait, termasuk pemilik data (Kominfo 2015).

Asas yang terdapat di dalam RUU Perlindungan Data Pribadi yang telah disebutkan diatas sejalan dengan teori pertanggungjawaban yang dimotori oleh Hans Kelsen menyatakan bahwa "Seseorang bertanggung jawab secara hukum atas suatu perbuatan tertentu atau bahwa dia memikul 
tanggung jawab hukum, subyek berarti bahwa dia bertanggung jawab atas suatu sanksi dalam hal perbuatan yang bertentangan" (Area 1997).

2) Jangkauan RUU Perlindungan Data Pribadi

Maksud dari pada jangkauan RUU Perlindungan Data Pribadi ini adalah untuk memberikan batasan hak dan kewajiban terhadap setiap tindakan perolehan dan pemanfaatan (pengelolaan) semua jenis data pribadi baik yang dilakukan di Indonesia maupun data pribadi warga Indonesia di luar negeri, baik dilakukan oleh perorangan maupun badan hukum (badan publik, swasta, dan organisasi kemasyarakatan (Kominfo 2015).

3) Arah Pengaturan dan Ruang Lingkup RUU Perlindungan Data Pribadi

a. Ketentuan Umum

Hal-hal yang terdapat dalam ketentuan umum ini yakni asas, maksud dan tujuan dimuat dalam ketentuan Undang-Undang serta batasan pengertian yang digunakan, seperti: Data Pribadi, Informasi, Data Pribadi Sensitif, Proses Data Pribadi, File Data Pribadi, Pengelola Data Pribadi, Pemroses Data Pribadi, Pemilik Data Pribadi, Pengelolaan Data Pribadi, Kepentingan Umum, Privasi Data Pribadi, Pemasaran Langsung, Komisi, Transfer Data Pribadi, Pihak Ketiga, Transaksi Bisnis, Badan Publik, Badan Hukum Publik, Badan Hukum Swasta, Badan Usaha Perorangan, Organisasi kemasyarakatan, Setiap Orang, Alat Pemroses/Pengolah Data Visual/CCTV. Dengan demikian ketentuan umum dalam RUU Perlindungan Data Pribadi telah mengatur lebih spesifik dibanding beberapa Undang-Undang yang telah ada.

b. Materi Yang Akan Diatur

Dalam RUU Perlindungan Data Pribadi pengelolaan data pribadi sensitif merupakan agenda yang substansial di dalam RUU tersebut, karena data pribadi sensitif dalam Naskah Akademik (Kominfo 2015) "Merupakan data dan informasi yang berkaitan dengan agama/keyakinan, kesehatan, kondisi fisik dan kondisi mental, kehidupan seksual, data keuangan pribadi, data pendidikan, serta data dan informasi pribadi lainnya yang mungkin dapat membahayakan dan merugikan privasi pemilik data".

Selain dari pada itu, RUU Perlindungan Data Pribadi juga mengatur hak-hak pemilik data pribadi antara lain:

i. Hak untuk mengajukan permintaan akses yang memadai dan salinan atas data pribadi miliknya kepada pengelola data pribadi yang mengelola data pribadi miliknya.

ii. Hak untuk meminta pengelola data memperbaiki kesalahan dan ketidakakuratan, dan memperbaharui data pribadi yang berada di dalam pengelolaan pengelola data pribadi.

iii. Hak untuk melengkapi data dan pribadi sebelum data dan pribadi tersebut dikelola oleh pengelola data pribadi. 
iv. Hak untuk meminta kepada pengelola data pribadi untuk memusnahkan data pribadi.

v. Hak untuk menuntut dan menerima ganti rugi atas pelanggaran terhadap hak-haknya.

vi. Hak untuk dapat setiap saat menarik kembali persetujuan pengelolaan data yang telah diberikan pada pengelola data dengan pemberitahuan.

Namun demikian dalam RUU Perlindungan Data Pribadi mengatur mengenai pengecualian, akan tetapi hal tersebut dalam keadaan-keadaan tertentu serta dengan alasan yang sah diatur oleh Undang-Undang, antara lain: Keamanan nasional, kepentingan proses penegakan hukum, kepentingan pers sepanjang data pribadi diperoleh dari informasi yang sudah dipublikasikan, kepentingan penelitian ilmiah dan statistik.

Selanjutnya mengenai kewajiban pengelola data pribadi yang mencakup beberapa kewajiban yakni:

i. Kewajiban untuk memperoleh persetujuan dari pemilik data, artinya pengelola data pribadi harus mendapatkan persetujuan, guna memberikan informasi kepada pemilik data pribadi mengenai legalitas dari pengelola data pribadi, tujuan pengelolaan data pribadi, jenis-jenis data pribadi yang akan dikelola, periode retensi dokumen yang memuat data pribadi, rincian mengenai informasi apa saja yang dikumpulkan, jangka waktu pengelolaan dan pemusnahan data pribadi, dan juga pemilik data pribadi mempunyai hak untu menolak memberikan persetujuaan.

ii. Kewajiban untuk tidak mencegah atau melarang pemilik data menarik kembali persetujuan pengelolaan data pribadi

iii. Kewajiban menghentikan pengelolaan data pribadi segera setelah pemilik data menarik persetujuan pengelolaan data pribadi.

iv. Kewajiban menunda proses pengelolaan data pribadi sebagian atau seluruhnya apaila pemilik data pribadi meminta penundaan..

v. Kewajiban untuk mengumumkan kebijakan perlindungan privasi mengenai data pribadi.

vi. Kewajiban melindungi dan memastikan keamanan data pribadi.

vii. Kewajiban untuk memberikan akses kepada pemilik data pribadi apabila terdapat permintaan akses dari pemilik data.

viii. Kewajiban untuk memperbaiki kesalahan dan atau ketidakakuratan data pribadi pengelola data pribadi dengan alasan yang wajar mengemukakan pada pemilik data pribadi.

ix. Kewajiban untuk melakukan pengawasan yang tepat terhadap orang yang terlibat dalam proses pengelolaan data pribadi di bawah perintah dan pengawasan pengelola data pribadi.

x. Kewajiban untuk melakukan usaha yang wajar untuk memastikan data pribadi yang dikelolah akurat dan lepangkap apabila data pribadi akan digunakan untuk membuat suatu keputusan yang mempengaruhi pemilik data pribadi, dan data pribadi akan diungkapkan kepada pihak lain berdasarkan persetujuan pemilik data pribadi. 
Urgensi Pengesahan Rancangan Undang-Undang Perlindungan Data Pribadi Demi Mewujudkan Kepastian Hukum

xi. Kewajiban untuk memastikan perlindungan data pribadi dari permintaan, pengumpulan, penggunaan, pengelolahan dan pengungkapan yang tidak sah.

xii. Kewajiban untuk melindungi data pribadi yang dikelolanya dengan membuat sistem keamanan yang dapat mencegah akses yang tidak sah, pengumpulan, penggunaan, pengelolahan, pengungkapan, modifikasi, penghapusan yang tidak sah atau tindakan lainnya.

xiii. Kewajiban untuk melakukan pemberitahuan pada pemilik data yang dirugikan tanpa pendaan fakta bahwa data pribadi miliknya terungkap.Kewajiban untuk menginformasikan pemasangan alat pemroses data visual ke masyarakat dan menjamin keamanan data pribadi yang diperolehnya dari alat pemroses data visual.

Di dalam RUU Perlindungan Data Pribadi juga telah mengatur mengenai penyelesaian sengketa yakni melalui penyelesaian di luar pengadilan dan melalui pengadilan. Namun demikian, penyelesaian di luar pengadilan harus dilakukan secara suka rela oleh para pihak yang bersengketa tanpa adanya paksaan. Jika penyelesaian diluar pengadilan tidak mendapatkan hasil para pihak dapat menyelesaikan perkara tersebut ke pengadilan. Sedangkn untuk ketentuan sanksi di dalam RUU Perlindungan Data Pribadi ditetapkan sanksi yang proporsional dengan perbuatan/pelanggaran yang dilakukan, selain dari pada itu juga penerapan sanksi untuk memberikan efek jera sera diterapkan untuk memberikan edukasi untuk merubah perilaku publik untuk lebih memahami perlunya menghargai hak privasi atas data pribadi. Terlepas dari pada itu sanksi tersebut berupa sanksi pidana dan sanksi perdata ganti rugi. Hal ini dapat juga melihat pada Undang-Undang Perlindungan Data di setiap negara yang menerapkan sanksi pidana, hal ini dilakukan karena kasus pencurian data pribadi yang mengarah kepada tindak kriminal. Disamping itu penetapan besaran sanksi dapat dirumuskan dengan kesesuaian kepada peraturan perundang-undangan yang berlaku. Oleh karena itu penetapan sanksi perlu dilengkapi dengan mekanisme penegakan hukumnya yang disesuaikan dengan ketentuan peraturan perundang-undangan yang berlaku.

\section{Kesimpulan}

Dari hasil pembahasan diatas maka dapat disimpulkan bahwa RUU Perlindungan Data Pribadi memang perlu untuk segerah disahkan mengingat banyak hal yang mendorong RUU tersebut, diantaranya mengenai peningkatan kasus pembobolan data pribadi, melindungi dan menjamin hak dasar warga negara, serta agar memberikan kepastian hukum kepada warga negara. Sehingga dengan adanya RUU Perlindungan Data Pribadi ini dapat mengakomodir beberapa asas-asas hukum nasional, mulai dari keadilan, kepastian dan kemanfaatan hukum. Selanjutnya mengenai konsep RUU Perlindungan Data Pribadi merupakan upaya pemerintahan untuk membangun landasan atau aturan yang khusus dan komprehensif demi menjaga data pribadi khususnya 
mengenai hak privasi masyarakat Indonesia, terlebih lagi tuntutan di era kemajuan teknilogi membuat kejahatan semakin komplek dan tak terbatas. RUU Perlindungan Data Pribadi ini disamping mengenai aturan yang khusus dan komprehensif juga dapat mengharmonisasikan kehadiran undang-undang dari masing-masing sektor kerja seperti yang terdapat pada undang-undang ITE dan turunannya. Dengan adanya konsep perlindungan data pribadi ini tentu dapat melindungi data pribadi individu terhadap penyalahgunaan pengumpulan, khususnya bagi konsumen yang sangat membutuhkan perlindungan hukum terutama di era dimana data pribadi menjadi lebih sangat berharga bagi kepentingan bisnis, menimbulkan kekhawatiran bahwa data pribadi konsumen dijual atau digunakan tanpa adanya persetujuan mereka. Maka demikian untuk memprioritaskan RUU Perlindungan Data Pribadi segera disahkan. 
Urgensi Pengesahan Rancangan Undang-Undang Perlindungan Data Pribadi Demi Mewujudkan Kepastian Hukum

\section{BIBLIOGRAFI}

Area, Universitas Medan. (1997). “Xxvii Universitas Medan Area.":9-32. file:///C:/Users/ASUS/Documents/teori kebijakan.pdf.

Bakhri, Syaiful. (2018). Ilmu Negara Dalam Dalam Pergumulutan Filsafat, Sejarah Dan Negara Hukum. Depok: Raja Grafindo.

Dewi, Sinta. (2016). Konsep Perlindungan Hukum Atas Privasi Dan Data Pribadi Dikaitkan Dengan Penggunaan Cloud Computing Di Indonesia. Yustisia Jurnal Hukum 5(1): 22-30. Google Scholar

Djafar, Wahyudi, and Asep Komarudin. (2014). Perlindungan Hak Atas Privasi Di InternetBeberapa Penjelasan Kunci. Elsam: 2. https://elsam.or.id/perlindungan-hak-atas-privasi-diinternet-beberapa-penjelasan-kunci/. Google Scholar

Gunakaya, A. Widiada. (2017). Hukum Hak Asasi Manusia. Yogyakarta: Andi. Google Scholar

Huijbers, Theo. (1982). Filsafat Hukum Dalam Lintasan Sejarah. Jakarta: Kanisius. Google Scholar

Jumiati. (2006). Negara Hukum Dan Hak Asasi Manusia. Jurnal Demokrasi Vol.V(No.2): 178. Google Scholar

Kania Dewi Andhika Putri, Ridwan Arifin. (2018). Tinjauan Teoritis Keadilan Dan Kepastian Dalam Hukum Indonesia. Jurnal Mimbar Yustitia 2(2): 148-49. Google Scholar

Komin. (2021). “Kominfo.” https://kominfo.go.id/content/detail/35104/ruu-pdp-jaminperlindungan-data-pribadi-yang-progresif-dan-komprehensif/0/berita_satker.

Kominfo. (2015). Naskah Akademik RUU Perlindungan Data Pribadi. 116. Google Scholar

Lubis, M. Solly. (2009). Ilmu Pengetahuan Perundang-Undangan. Bandung: Mandar Maju. Google Scholar

M.Wantu, Fence. (2007). Antinomi Dalam Penegakan Hukum Oleh Hakim. Jurnal Berkala Mimbar Hukum. 19(3): 388. Google Scholar

Marbun, S.F dan Mahfud M.D. (2006). Pokok-Pokok Hukum Administrasi Negara. Yogyakarta: Liberty.

Mario Julyano, Aditya Yuli Setiawan. (2019). Pemahaman Terhadap Asas Kepastian Hukum Melalui Konstruksi Penalaran Positivisme Hukum.Jurnal Crepido 1(1): 13. Google Scholar

Pratiwi, Cekli Setya, Cristina Yulita, Fauzi, and Shinta Ayu Purnamawati. (2016). Penjelasam Hukum: Asas-Asas Umum Pemerintahan Yang Baik (AUPB) Hukum Administrasi. Judicial Sector Support Program: 1-132.

Prayogo, R Tony. (2016). Penerapan Asas Kepastian Hukum Dalam Peraturan Mahkamah Agung Nomor 1 Tahun 2011 Tentang Hak Uji Materiil Dan Dalam Peraturan Mahkamah Konstitusi Nomor 06/PMK/2005 Tentang Pedoman Beracara Dalam Pengujian UndangUndang. Jurnal Legislasi Indonesia 13(2): 194. Google Scholar 
Nurmalasari

Rahardjo, Satjipto. (2000). Ilmu Hukum. Bandung: Citra Aditya Bhakti.

Rahardjo. (2012). Ilmu Hukum. Bandung: Aditya Bakti. Google Scholar

Sautunnida, Lia, Kanun Jurnal, and Ilmu Hukum. (2012). Perlindungan Hukum Bagi Nasabah Yang Mengalami Kerugian Dalam Transaksi Perbankan Melalui Internet. Kanun: Jurnal Ilmu Hukum 14(1): 37-52. Google Scholar

Setiadi, H.E. (2017). Sistem Peradilan Pidana Terpadu Dan Sistem Penegakan Hukum Di Indonesia,. Jakarta: Prenada Media. Google Scholar

Sinaga, Erlina Maria Christin. (2020). Formulasi Legislasi Perlindungan Data Pribadi. Jurnal RechtVinding 9(2): 237-56. Google Scholar

sinta.unud.ac.id. Tinjauan Umum Tentang Perlindungan Hukum Data Pribadi Dan Gojek. Sinta Unud. https://sinta.unud.ac.id/uploads/wisuda/1203005305-3-BAB II.pdf.

Suliantoro, Oleh B Wibowo. (2017). Dinamika Arah Kepastian Hukum Di Tengah Transformasi Sosial-Budaya Dalam Perspektif Pemikiran Mazhab Sociological Jurisprudence. Jurnal Filsafat 17(1): 15-31. Google Scholar

Syahrani, Riduan. (1999). Rangkuman Intisari Ilmu Hukum. Bandung: Citra Aditya Bakti. Google Scholar

Syarpani. (2014). Tinjauan Yuridis Terhadap Perlindungan Data Pribadi Di Media Elektronik (Berdasarkan Pasal 25 Undang-Undang Nomor 11 Tahun 2008 Tentang Informasi Dan Transaksi Elektronik. Beraja Niti Vol.3(No.6): 7. Google Scholar

Tekno.tempo.co. Pencurian Data Pribadi Nyata Ini Heboh 11 Serangan Siber Sepanjang 2020. tekno.tempo.co. https://tekno.tempo.co/read/1417180/pencurian-data-pribadi-nyata-iniheboh-11-serangan-siber-sepanjang-2020.

Upik Mutiara, Romi Maulana. (2020). Perlindungan Data Pribadi Sebagai Bagian Dari Hak Asasi Manusia Atas Perlindungan Diri Pribadi. Journal of Law and Policy Studies Vol.1(No.1): 47. Google Scholar

Wahyudi Djafar, M. Jodi Santoso. (2019). Perlindungan Data Pribadi: Konsep, Instrumen, Dan Prinsipnya, Lembaga Studi Dan Advoksi Masyarakat (ELSAM. Jakarta: ELSAM.

Winarno. (2007). Paradigma Baru Pendidikan Kewarganegaraan: Panduan Kuliah Di Perguruan Tinggi. Jakarta: Bumi Aksara.

\section{Copyright holder:}

Nurmalasari (2021)

First publication right:

Syntax Idea

This article is licensed under: 